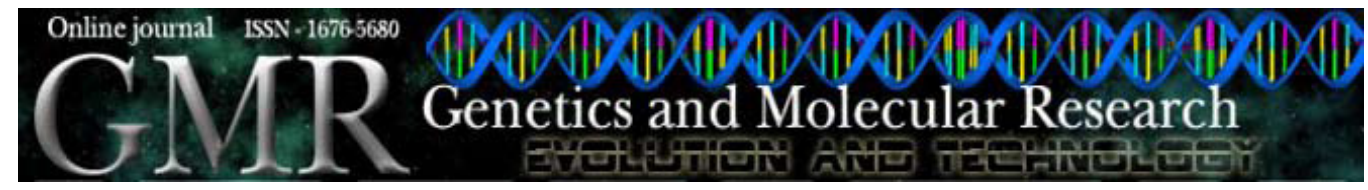

\title{
Application of RAPD for molecular characterization of plant species of medicinal value from an arid environment
}

\author{
I.A. Arif, M.A. Bakir, H.A. Khan, A.H. Al Farhan, A.A. Al Homaidan, \\ A.H. Bahkali, M. Al Sadoon and M. Shobrak \\ Molecular Fingerprinting and Biodiversity Unit, \\ Prince Sultan Research Chair for Environment and Wildlife, \\ College of Sciences, King Saud University, Riyadh, Saudi Arabia \\ Corresponding author: H.A. Khan \\ E-mail: khan_haseeb@yahoo.com
}

Genet. Mol. Res. 9 (4): 2191-2198 (2010)

Received May 11, 2010

Accepted September 29, 2010

Published November 9, 2010

DOI 10.4238/vol9-4gmr848

\begin{abstract}
The use of highly discriminatory methods for the identification and characterization of genotypes is essential for plant protection and appropriate use. We utilized the RAPD method for the genetic fingerprinting of 11 plant species of desert origin (seven with known medicinal value). Andrachne telephioides, Zilla spinosa, Caylusea hexagyna, Achillea fragrantissima, Lycium shawii, Moricandia sinaica, Rumex vesicarius, Bassia eriophora, Zygophyllum propinquum subsp migahidii, Withania somnifera, and Sonchus oleraceus were collected from various areas of Saudi Arabia. The five primers used were able to amplify the DNA from all the plant species. The amplified products of the RAPD profiles ranged from 307 to $1772 \mathrm{bp}$. A total of 164 bands were observed for 11 plant species, using five primers. The number of well-defined and major bands for a single plant species for a single primer ranged from 1 to 10 . The highest pair-wise similarities $(0.32)$ were observed between A. fragrantissima and $L$. shawii, when five primers were combined. The lowest similarities (0) were observed between $A$. telephioides and $Z$. spinosa; Z. spinosa and B. eriophora; B. eriophora and Z. propinquum.
\end{abstract}


In conclusion, the RAPD method successfully discriminates among all the plant species, therefore providing an easy and rapid tool for identification, conservation and sustainable use of these plants.

Key words: Molecular fingerprinting; Medicinal plants; RAPD; Arid environment

\section{INTRODUCTION}

Plant species of the desert are adapted to tolerate multiple stresses including drought, high temperature, high solar radiation, high wind, and salinity (Batanouny, 2001). It is noteworthy that besides their medicinal value, endangered mammals feed on many of the herbal plants growing in the desert. Recently, it was determined that about $35 \%$ of the species that constitute the standing vegetation are vulnerable to elimination because they are not represented in the seed bank of the Red Sea area (Hegazy et al., 2009). Therefore, appropriate measures for the preservation of plant species in the desert area are urgently needed. Proper identification is crucial for the preservation of plants growing in extreme arid regions. Traditionally, subjective methods based on the morphological features such as shape, color, texture, and odor are used for the discrimination of herbal medicines. However, these methods are difficult to apply accurately for discrimination and authentication. The use of chromatographic techniques and marker compounds to standardize botanical preparations is also limited because the medicines have variable sources and chemical complexity, which is affected by growth, storage conditions and harvest times (Joshi et al., 2004; Zhang et al., 2007).

Among the polymerase chain reaction (PCR)-based molecular techniques, random amplified polymorphic DNA (RAPD) is convenient in performance and does not require any information about the DNA sequence to be amplified (Weder, 2002). Due to its procedural simplicity, the use of RAPD as molecular markers for taxonomic and systematic analyses of plants (Bartish et al., 2000), as well as in plant breeding and the study of genetic relationships, has considerably increased (Ranade et al., 2001). Recently, RAPD has been used for the estimation of genetic diversity in various endangered plant species (Wang et al., 2005; Lu et al., 2006; Liu et al., 2007; Zheng et al., 2008). In this study, we successfully utilized the RAPD technique for rapid characterization of 11 plant species of the Saudi Arabian desert.

\section{MATERIAL AND METHODS}

\section{Plant samples}

The young shoots (with intact leaves) from 11 plant species, 7 of them with known medicinal value, were collected from different regions of Saudi Arabia. The samples were individually placed in sealable polythene bags, transported to laboratory, and then kept frozen until DNA extraction. A detailed description of these plant species is given in Table 1.

\section{Genomic DNA isolation}

Genomic DNA was isolated from leaf samples. Leaf samples were placed in a sterile 


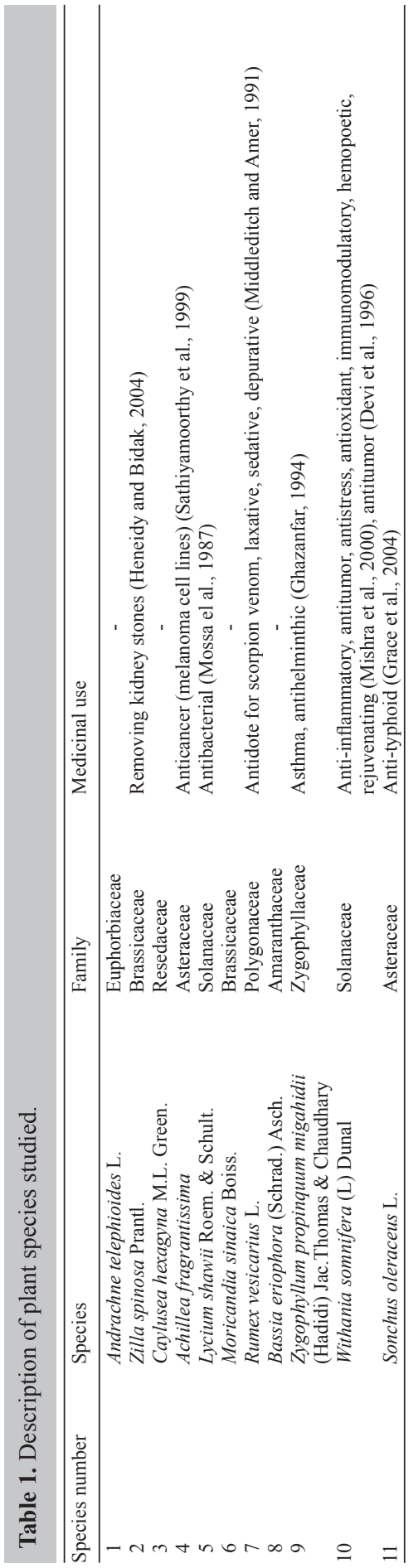


mortar containing liquid nitrogen and thoroughly crushed with a sterile pestle. The powdered leaves were subjected to DNA extraction. An anion exchange chromatography-based DNeasy Plant Mini Kit (Qiagen, Valencia, CA, USA) was used for genomic DNA isolation and purification. The purity and quantity of isolated DNA were determined spectrophotometrically (GeneQuant-1300; GE Healthcare, Buckinghamshire, UK).

\section{RAPD-PCR analysis}

Ready-To-Go RAPD analysis beads (GE Healthcare, Buckinghamshire, UK) were used for RAPD-PCR analysis. The PCR mixture of $25 \mu \mathrm{L}$ contained a single Ready-To-Go RAPD analysis bead, $25 \mathrm{pmol}$ of a single RAPD primer, $50 \mathrm{ng}$ of template DNA and sterile distilled water. The bead contained thermostable polymerase (AmpliTaq ${ }^{\mathrm{TM}}$ DNA polymerase and Stoffel fragment), dNTPs ( $0.4 \mathrm{mM}$ each), BSA $(2.5 \mu \mathrm{g})$ and buffer $(3 \mathrm{mM} \mathrm{MgCl}, 30 \mathrm{mM}$ $\mathrm{KCl}$ and $10 \mathrm{mM}$ Tris, $\mathrm{pH} \mathrm{8.3).} \mathrm{Five} \mathrm{primers} \mathrm{(GE} \mathrm{Healthcare)} \mathrm{were} \mathrm{used} \mathrm{in} \mathrm{this} \mathrm{study.} \mathrm{Each}$ primer is a 10-mer of arbitrary sequence: a (5-GGTGCGGGAA-3), b (5-GTTTCGCTCC-3), c (5-GTAGACCCGT-3), d (5-AACGCGCAAC-3), and e (5-CCCGTCAGCA-3).

PCR was performed using a Veriti 96-well thermal cycler (Applied Biosystems, USA). PCR conditions included 1 cycle of $95^{\circ} \mathrm{C}$ for $5 \mathrm{~min}$, followed by 45 cycles of $95^{\circ} \mathrm{C}$ for $1 \mathrm{~min}, 36^{\circ} \mathrm{C}$ for $1 \mathrm{~min}$ and $72^{\circ} \mathrm{C}$ for $2 \mathrm{~min}$. A long $(20 \times 14 \mathrm{~cm}) 1 \%$ agarose gel using $1 \mathrm{X}$ TAE buffer containing $0.5 \mu \mathrm{g} / \mathrm{mL}$ ethidium bromide was used for electrophoresis of products. Gel images were obtained using Proxima C16 Phi+ (Isogen Life Science) UV transilluminator and Opticom (version 3.2.5; OptiGo) imaging system. Gel image analysis of the RAPD bands obtained for the different taxa using different RAPD primers was performed using an Amersham 100-bp ladder (GE Healthcare) and the TotalLab TL100 1D software (version 2008.01).

\section{Data analysis}

RAPD-PCR-amplified fragments were scored as present (1) or absent (0). Only clear and major bands were scored (Collard and Mackill, 2009). Pairwise comparisons between accessions, based on the proportion of shared bands produced by the primers used, were calculated using the Jaccard's similarity coefficient with the help of the StatistiXL program (version 1.7).

\section{RESULTS}

The RAPD banding patterns of the 11 plant species are illustrated in Figure 1. The 5 primers (a to e) used for RAPD-PCR were able to amplify the DNA from all the plant species studied. The RAPD profiles using all samples generated amplified products ranging from 307 to $1772 \mathrm{bp}$. A total of 164 bands were observed for 11 plant species using 5 primers. The number of well-defined and major bands for a single plant species for a single primer ranged from 1 to 10 . For 11 plant species, the maximum number of well-defined or major bands was observed with primer a (43 bands) and the minimum number with primer e (19 bands) (Figure 1).

Primers a and $\mathrm{b}$ produced distinct banding patterns for all the plant species tested. Pairwise similarities based on the proportion of shared bands with the primers used were calculated and the results are given in Table 2. Pairwise similarity of banding pattern between the plant species studied ranged from 0 to 0.6 for primers a and b. However, primers c, $d$ and e did 
not show discriminatory bands for all the plant species. A similar banding pattern was observed for Zygophyllum propinquum, Withania somnifera and Sonchus oleraceus using primer c (pairwise similarity value, 1.0). With primer d, Zilla spinosa and Achillea fragrantissima showed a similar banding pattern (pairwise similarity value, 1.0). Bands obtained with primer e showed similarities between Caylusea hexagyna and A. fragrantissima. The same type of banding pattern was also found for Z. propinquum and S. oleraceus with primer e.

Overall, pairwise similarity for all 5 primers ranged from 0 to 0.3 . The highest pairwise similarity (0.32) was observed between A. fragrantissima and Lycium shawii, when 5 primers were combined. The lowest pairwise similarity ( 0 ) was observed between Andrachne telephioides and Z. spinosa, Z. spinosa and Bassia eriophora, and B. eriophora and Z. propinquum.

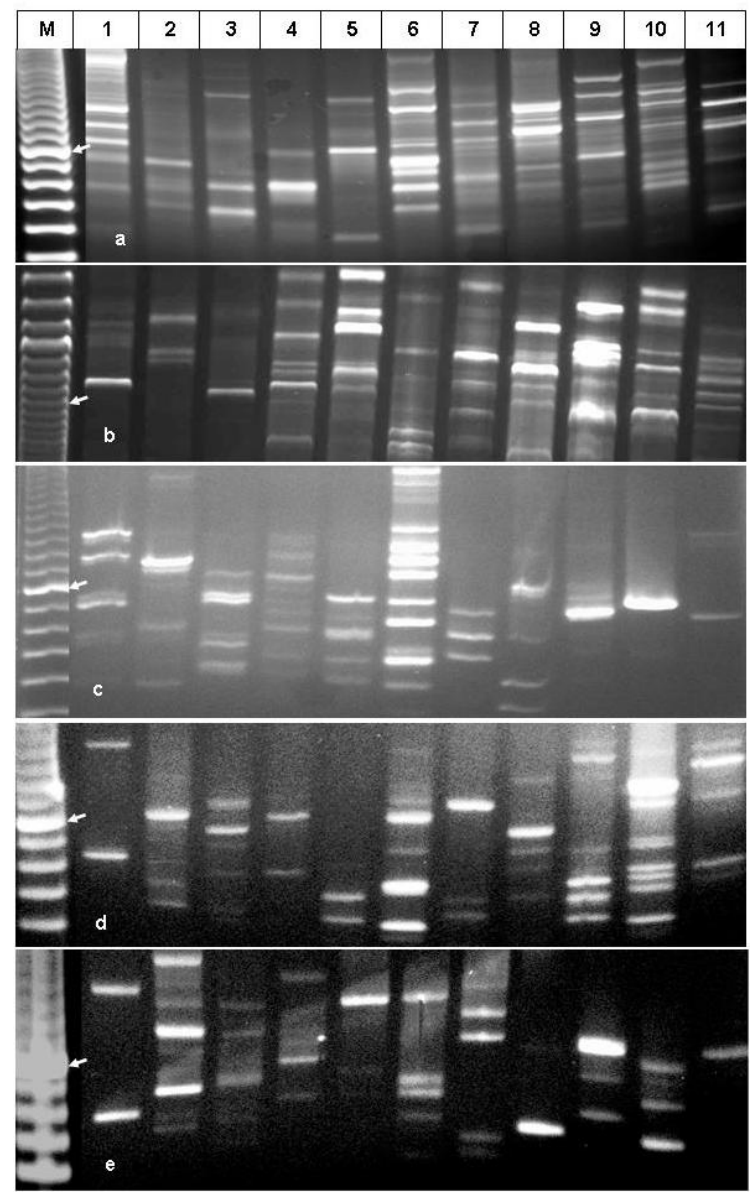

Figure 1. RAPD-PCR product profiles of 11 plant species. Lane $M=100$-bp molecular weight marker; lane 1 $=$ Andrachne telephioides (Euphorbiaceae); lane $2=$ Zilla spinosa (Brassicaceae); lane $3=$ Caylusea hexagyna (Resedaceae); lane $4=$ Achillea fragrantissima (Asteraceae); lane $5=$ Lycium shawii (Solanaceae); lane $6=$ Moricandia sinaica (Brassicaceae); lane $7=$ Rumex vesicarius (Polygonaceae); lane $8=$ Bassia eriophora (Chenopodiaceae); lane $9=$ Zygophyllum propinquum subsp migahidii (Zygophyllaceae); lane $10=$ Withania somnifera (Solanaceae), and lane 11 = Sonchus oleraceus (Asteraceae); a, b, c, d, e: RAPD primers. Arrows indicate the 800-bp position of the molecular weight marker. 
Table 2. Similarity matrix for 11 plant species based on RAPD banding pattern.

\begin{tabular}{|c|c|c|c|c|c|c|c|c|c|c|}
\hline Plant species & 1 & 2 & 3 & 4 & 5 & 6 & 7 & 8 & 9 & 10 \\
\hline \multicolumn{11}{|l|}{ 1. A. telephioides } \\
\hline 2. Z. spinosa & 0.00 & & & & & & & & & \\
\hline 3. C. hexagyna & 0.04 & 0.05 & & & & & & & & \\
\hline 4. A. fragrantissima & 0.09 & 0.21 & 0.19 & & & & & & & \\
\hline 5. L. shawii & 0.20 & 0.05 & 0.14 & 0.32 & & & & & & \\
\hline 6. M. sinaica & 0.22 & 0.19 & 0.22 & 0.21 & 0.18 & & & & & \\
\hline 7. R. vesicarius & 0.18 & 0.04 & 0.18 & 0.13 & 0.13 & 0.17 & & & & \\
\hline 8. B. eriophora & 0.13 & 0.00 & 0.13 & 0.08 & 0.08 & 0.08 & 0.12 & & & \\
\hline 9.Z. propinquum & 0.08 & 0.14 & 0.08 & 0.12 & 0.29 & 0.14 & 0.12 & 0.00 & & \\
\hline 10. W. somnifera & 0.13 & 0.06 & 0.21 & 0.16 & 0.25 & 0.19 & 0.23 & 0.16 & 0.27 & \\
\hline 11. S. oleraceus & 0.14 & 0.05 & 0.14 & 0.09 & 0.09 & 0.03 & 0.13 & 0.13 & 0.35 & 0.13 \\
\hline
\end{tabular}

\section{DISCUSSION}

Besides the use of a particular type of molecular marker, molecular characterization also depends on successful isolation of quality DNA. Problems are reported for the isolation of plant DNA. Isolated DNA contains colored substances, polysaccharides and phenolic compounds (Aras et al., 1993; Temiesak et al., 1993; Vanijajiva et al., 2005). The use of DNeasy Plant Mini Kit allowed the isolation of DNA from the plants studied, which we found suitable for RAPD-PCR amplification.

RAPD has frequently been used for the detection of genetic variability in plants. The advantages of this method are its rapidity, simplicity and lack of need for any prior genetic information about the plant. RAPD patterns are consistent irrespective of the plant source or age (Welsh and McClelland, 1990; Micheli et al., 1994). These characters are especially advantageous for the identification of herbal medicines because little DNA exists in the dried material and also because sequence data are difficult to obtain (Williams et al., 1990; Shinde et al., 2007). We characterized 11 plant species, of which 7 have known medicinal value (Table 1). RAPD has been successfully utilized for the identification of medicinal plants (Tochika-Komatsu et al., 2001; Um et al., 2001) and herbal medicinal components (Shinde et al., 2007). This technique has also been reported to be useful for the identification and genotyping of ornamental plants (De Benedetti et al., 2001) and other varieties of plant species (Temiesak et al., 1993).

Sequence-based analyses sometimes fail to distinguish between species because of the significant similarity between their DNA sequences in the amplified region. RAPD primers are able to distinguish taxa below the species level (Choo et al., 2009), because RAPD analysis reflects both coding and non-coding regions of the genome (Vanijajiva et al., 2005). However, some of the problems with RAPD are related to reproducibility, designing appropriate primers and amplification of RAPD-PCR products. PCR conditions constitute one of the crucial factors for obtaining amplified products, especially for plants (Jones et al., 1997). It is suggested that if the overall temperature profiles (especially the annealing temperature) inside the PCR tubes are identical, RAPD fragments are then likely to be reproducible (Penner et al., 1993; Skroch and Nienhuis, 1995). Our study showed that the protocol used worked well for the 11 plant species studied. The PCR product obtained enabled us to distinguish the 11 plant species even with the use of a single primer a or primer $b$ (pairwise similarity level ranged from 0 to 0.6). However, the combination of 5 primers showed better resolution (pairwise similarity level ranged from 0 to 0.3 ). These data corroborate other findings indicating that the combination of primers provides better resolution (Temiesak et al., 1993; Vanijajiva et al., 2005). 
The identification of desert plants is crucial for their preservation and sustainable use, as well as to prevent forgery in the marketing of medicinal plants. Expected chemicals in the herbal plant targeted for medicinal use could vary with the genomic or environmental variability of the species (Echeverrigaray et al., 2001). RAPD fingerprinting was used for the detection of variety (Temiesak et al., 1993) and clonal variation of plant species (Wang et al., 2009). RAPD provides rapid results, is less time-consuming and less expensive (Arif and Khan, 2009), and gives information about genomic variability below the species level (Williams et al., 1990). Primers and chemicals required for PCR used in this study are readily available on the market. Laboratories without expensive sequencing instrumentation would be able to identify the plant species studied. Therefore, our findings provide guidance for the identification of these plant species growing in an extreme arid environment, to help in their subsequent management and utilization in sustainable ways to combat human and natural pressures on these valuable natural resources.

\section{ACKNOWLEDGMENTS}

Research supported by the Prince Sultan Research Chair for Environment and Wildlife, Riyadh, Saudi Arabia. The authors thank Dr. Jacob Thomas for the identification and collection of plant specimens and Anis Ahamed for DNA extraction.

\section{REFERENCES}

Aras S, Duran A and Yenilmez G (1993). Isolation of DNA for RAPD analysis from dry leaf material of some Hesperis L. specimens. Plant Mol. Biol. Rep. 21: 461a-461f.

Arif IA and Khan HA (2009). Molecular markers for biodiversity analysis of wildlife animals: a brief review. Anim. Biodiv. Conserv. 32: 9-16.

Bartish IV, Garkava LP, Rumpunen K and Nybom H (2000). Phylogenetic relationship and differentiation among and within population of Chaenomeles Lindl. (Rosaceae) estimated with RAPDs and isozyme. Theor. Appl. Genet. 101: 554-563.

Batanouny KH (2001). Plants in the Deserts of the Middle East. Springer, New York.

Choo BK, Moon BC, Ji Y, Kim BB, et al. (2009). Development of SCAR markers for the discrimination of three species of medicinal plants, Angelica decursiva (Peucedanum decursivum), Peucedanum praeruptorum and Anthricus sylvestris, based on the internal transcribed spacer (ITS) sequence and random amplified polymorphic DNA (RAPD). Biol. Pharm. Bull. 32: 24-30.

Collard BCY and Mackill DJ (2009). Start codon targeted (SCoT) polymorphism: a simple, novel DNA marker technique for generating gene targeted markers in plants. Plant Mol. Biol. Rep. 27: 86-93.

De Benedetti L, Mercuri A, Bruna S, Burchi G, et al. (2001). Genotype identification of ornamental species by RAPD analysis. Acta Hort. 546: 391-394.

Devi PU, Akagi K, Ostapenko V, Tanaka Y, et al. (1996). Withaferin A: a new radiosensitizer from the Indian medicinal plant Withania somnifera. Int. J. Radiat. Biol. 69: 193-197.

Echeverrigaray S, Agostini G, Atti-Serfini L, Paroul N, et al. (2001). Correlation between the chemical and genetic relationships among commercial thyme cultivars. J. Agric. Food Chem. 49: 4220-4223.

Ghazanfar SA (1994). Handbook of Arabian Medicinal Plants. CRC Press, Florida.

Grace NN, Rainer BW, Barbara G, Eric NL, et al. (2004). Utilization of weed species as sources of traditional medicines in central Kenya. Lyonia 7: 71-87.

Hegazy AK, Hammouda O, Lovett-Doust J and Gomaa NH (2009). Variations of the germinable soil seed bank along the altitudinal gradient in the northwestern Red Sea region. Acta Ecol. Sin. 2: 20-29.

Heneidy SZ and Bidak LM (2004). Potential uses of plant species of the coastal Mediterranean region, Egypt. Pak. J. Biol. Sci. 7: 1010-1023.

Jones CJ, Edwards KJ, Castaglione S, Winfield MO, et al. (1997). Reproducibility testing of RAPD, AFLP and SSR 
markers in plants by a network of European laboratories. Mol. Breed. 3: 381-390.

Joshi K, Chavan P, Warude D and Patwardhan B (2004). Molecular markers in herbal drug technology. Curr. Sci. 87: 159-165.

Liu P, Yang YS, Hao CY and Guo WD (2007). Ecological risk assessment using RAPD and distribution pattern of a rare and endangered species. Chemosphere 68: 1497-1505.

Lu HP, Cai YW, Chen XY, Zhang X, et al. (2006). High RAPD but no cpDNA sequence variation in the endemic and endangered plant, Heptacodium miconioides Rehd. (Caprifoliaceae). Genetica 128: 409-417.

Micheli MR, Bova R, Pascale E and D'Ambrosio E (1994). Reproducible DNA fingerprinting with the random amplified polymorphic DNA (RAPD) method. Nucleic Acids Res. 22: 1921-1922.

Middleditch BS and Amer AM (1991). Kuwaiti Plants. In: Studies in Plant Science Elsevier Science, Amsterdam,

Mishra LC, Singh BB and Dagenais S (2000). Scientific basis for the therapeutic use of Withania somnifera (Ashwagandha): a review. Altern. Med. Rev. 5: 335-346.

Mossa JS, Al-Yahya MA and Al-Meshal IA (1987). Medicinal Plants of Saudi Arabia. King Saud University Press, Riyadh.

Penner GA, Bush A, Wise R, Kim W, et al. (1993). Reproducibility of random amplified polymorphic DNA (RAPD) analysis among laboratories. Genome Res. 2: 341-345.

Ranade SA, Farooqui N, Bhattacharya E and Verma A (2001). Gene tagging with random amplified polymorphic DNA (RAPD) marker for molecular breeding in plants. Crit. Rev. Plant Sci. 20: 251-275.

Sathiyamoorthy P, Lugasi-Evgi H, Schlesinger P, Kedar I, et al. (1999). Screening for cytotoxic and antimalarial activities in desert plants of the Negev and Bedouin market plant products. Pharm. Biol. 37: 188-195.

Shinde VM, Dhalwal K, Mahadik KR, Joshi KS, et al. (2007). RAPD analysis for determination of components in herbal medicine. Evid. Based Complement Alternat. Med. 4: 21-23.

Skroch P and Nienhuis J (1995). Impact of scoring error and reproducibility of RAPD data on RAPD based estimates of genetic distance. Theor. Appl. Genet. 91: 1086-1091.

Temiesak P, Ponpim Y and Harada T (1993). RAPD analysis for varietal identification in Brassica. Kasetsart J. Nat. Sci. 27: 37-42.

Tochika-Komatsu Y, Asaka I and Ii I (2001). A random amplified polymorphic DNA (RAPD) primer to assist the identification of a selected strain, aizu K-111 of Panax ginseng and the sequence amplified. Biol. Pharm. Bull. 24: 1210-1213.

Um JY, Chung HS, Kim MS, Na HJ, et al. (2001). Molecular authentication of Panax ginseng species by RAPD analysis and PCR-RFLP. Biol. Pharm. Bull. 24: 872-875.

Vanijajiva O, Sirirugsa P and Suvachittanont W (2005). Confirmation of relationships among Boesenbergia (Zingiberaceae) and related genera by RAPD. Biochem. Syst. Ecol. 33: 159-170.

Wang Y, Wang S, Zhao Y, Khan DM, et al. (2009). Genetic characterization of a new growth habit mutant in tomato (Solanum lycopersicum). Plant Mol. Biol. Rep. 27: 431-438. DOI:10.1007/s11105-009-0095-2.

Wang ZS, An SQ, Liu H, Leng X, et al. (2005). Genetic structure of the endangered plant Neolitsea sericea (Lauraceae) from the Zhoushan archipelago using RAPD markers. Ann. Bot. 95: 305-313.

Weder JKP (2002). Influence of experimental conditions on the reproducibility of RAPD-PCR identification of legumes and cereals. Lebensm. Wiss. Technol. 35: 233-238.

Welsh J and McClelland M (1990). Fingerprinting genomes using PCR with arbitrary primers. Nucleic Acids Res. 18: 7213-7218.

Williams JG, Kubelik AR, Livak KJ, Rafalski JA, et al. (1990). DNA polymorphisms amplified by arbitrary primers are useful as genetic markers. Nucleic Acids Res. 18: 6531-6535.

Zhang YB, Shaw PC, Sze CW, Wang ZT, et al. (2007). Molecular authentication of Chinese herbal materials. J. Food Drug Anal. 15: 1-9.

Zheng W, Wang L, Meng L and Liu J (2008). Genetic variation in the endangered Anisodus tanguticus (Solanaceae), an alpine perennial endemic to the Qinghai-Tibetan Plateau. Genetica 132: 123-129. 